\title{
SOCIALIZATION AND MENTORING ON INCREASING DEMOCRACY AWARENESS AND COMMUNITY PARTICIPATION IN THE IMPLEMENTATION OF VILLAGE LAW IN NGADILUWIH VILLAGE, NGADILUWIH SUB-DISTRICT, KEDIRI REGENCY - EAST JAVA
}

\author{
Elis Teti Rusmiati $1^{*}$, Andriansyah ${ }^{1}$ \\ ${ }^{1}$ Prof. Dr. Moestopo (Beragama) University \\ *elistetirusmiati@dsn.moestopo.ac.id
}

\begin{abstract}
The uproar on Law Number 6 of 2014 on Village (Village Law) is currently more focused on the issues of village funds. Democracy, which is actually the spirit of the Village Law, does not get much attention. The spirit promoted by the Village Law is paving the way for democracy at the village level after in the past, villages were more often positioned as a sub-ordination of development programs. Rural communities need to be given proper understanding of democracy and the courage to participate so that the goals of community empowerment contained in the Village Law are immediately achieved. The method used in this activity consists of several stages: (1) survey; (2) module making; (3) socialization; (4) mentoring; (5) evaluation. Participants in the activity were: village officials, heads of RT and RW, village heads and community leaders. The results of the activity indicated that after socialization and mentoring: (1) the knowledge and awareness of participants regarding democratic rights, especially those related to the Village Law, increases; (2) Participants have the courage and the skills to convey their aspirations in each discussion forum in the village; (3) The Village Development Work Plan (RKPDes) proposed as a condition for the Village Funds, was made entirely involving community participation so that the programs were expected to be more in line with the needs of the village community, because they were captured from the aspirations of the community.
\end{abstract}

Keywords: Village law, village funds, democracy awareness, community participation, program implementation

\section{INTRODUCTION}

A new era towards village independence has been initiated since the issuance of Laws of the Republic of Indonesia Number 6 of 2014 concerning Villages (Village Law). Article 78 of the Village Law states that the objectives of village development are to improve the welfare of rural communities and the quality of human life and poverty alleviation through the fulfillment of basic needs, the construction of village facilities and infrastructures, the development of local economic potentials, and sustainable use of natural and environmental resources.

Politically, this law gives the central government authority over the village government. Furthermore, the village government has the authority in the administration and operation of village governance, in order to increase the effectiveness of services to the community.

Economically, this law gives the village government the authority to manage regional finances and find legitimate sources of village incomes. In Article 72 paragraphs (1) and (2), it is stated that one source of village incomes comes from the APBN allocation by making village-based programs evenly and equitably effective. Funds originating from this APBN reach up to Rp 1.4 billion per year for each village.

This high budget is very tempting, so discussions related to Village Law are almost always focused on the Village Funds. Governance and predictions that may arise around the problem are just as if to be the main topic. Not many people pay attention to matters related to village democracy, even though this issue is very important. Actually democracy is even the spirit of the Village Law. 
The spirit promoted by the Village Law is paving the way for democracy at the village level. In the past, villages were more often positioned as sub-ordinations from the top government, both local and central government. Government development programs entering the village, in the past, were more instruction nuanced, not prioritizing community participation. With this Village Law, democratic practices at the village level are expected to realize a more participatory development process.

As it is well known, the main requirement for getting the village funds is the readiness of the village which is indicated by the fulfillment of several administrative requirements, which must have the documents: Village Medium-Term Development Plans (RPJMDes), Village Government Work Plan (RKPDes), and Village Revenues and Expenditures (APBDes). These village planning documents are compiled from the results of the village meeting which must involve the active participation of the community. The goal is that the development carried out by the village is in accordance with the needs of the community. This confirms that democracy is actually the spirit of the Village Law. The spirit promoted by the Village Law is paving the way for democracy at the village level.

This community service activity was carried out to take the Partner Village format that was promoted by the Directorate of Research and Community Service (DRPM) of the Higher Education with the aim of: (1) applying the results of previous research that was in accordance with the urgency of the needs of the village community; (2) assisting government programs in community development and village areas; (3) strengthening the synergy of universities (PT) with relevant stakeholders in village development; and (4) forming a Partner Village.

Provisions in the Village Law that provide space for village democracy can be seen in the norms governing village meetings (musdes). The musdes is a formal space provided by law for villagers to articulate their interests. Therefore, in the context of village democracy, musdes has a very important position because that is where a space for public participation is provided. Musdes is becoming increasingly important because the Law also states that strategic matters related to villages must be discussed in this meeting. The strategic matters referred to are village regulation, planning, cooperation, investment plans entering the village, the formation of Village Owned Enterprises (BUMDes), addition and release of village assets, and extraordinary events.

Villagers are also given the right to supervise government administration activities, implementation of development, village community development, and village community empowerment. This supervision process is supported by the regulation of information disclosure, which is guaranteed by the Village Law that villagers have the right to obtain information from the village government.

On the other hand, to ensure that democracy works well, the Village Law also regulates the obligation of the village government to compile reports on the implementation of village governance. The written report is then submitted to the Village Consultative Body $(B P D)$ and distributed and/or given to the villagers at the end of the budgeting year. Thus, it can be seen as a whole how democracy is grown by the Village Law, and the performance and programs of the village cannot be separated from the participation of the community.

The uproar of the Village Law talks has so far revolved around concerns about the application of the Village Law, in addition to its optimism side. This concern is understandable given the size of the village authority as the Village Law provides the principle of regulation through 13 principles which include recognition and subsidiarity. The principle of recognition referred to in article 3 of the Village Law is the recognition of origin rights. The principle of subsidiarity is the determination of local scale authority and decision making locally for the benefit of villagers. With the principles of recognition and subsidiarity which are new clauses in the Village Law, it results in a consequence that a village has its own budget in managing village development.

The principles of recognition and subsidiarity which give greater authority to the village, makes the village position stronger than before so that the relationship is equal to the state. A village is no longer a quasi-government that is the catalyst of the project or administrative area, but it has autonomy in managing its development policies. In this position, village democracy becomes an important node for the people to access state resources managed by the village and make the village fully sovereign. 


\section{METHOD}

This community service activity was carried out Ngadiluwih Village, Ngadiluwih Sub-District, Kediri Regency, East Java. This location was chosen because it has a strong history, the birthplace of a national hero, Prof. Dr. Moestopo who is also the founder of University of Prof. Dr. Moestopo (Beragama).

The method used in this activity in addition to socialization is by mentoring. Through mentoring, it is expected that the community will come up with courage and self-confidence to be accustomed to expressing opinions and actively participating in each decision making in village meetings.

The stages carried out include: (1) initial surveys and mapping; (2) module making; (3) socialization; (4) mentoring in a number of meetings; and (5) evaluation (table 1), with success indicators including: (1) Knowledge and awareness of democracy, (2) Ability to capture/bring up ideas, (3) Courage to deliver aspirations/ideas (table 2).

Table 1. Stages of Community Service Activity

\begin{tabular}{|c|l|l|l|l|}
\hline \multirow{2}{*}{$\begin{array}{c}\text { N } \\
\text { o }\end{array}$} & \multicolumn{1}{|c|}{ Activity } & \multicolumn{1}{|c|}{ Lecturers } & \multicolumn{1}{c|}{ College Students } & \multicolumn{1}{c|}{ Community } \\
\cline { 3 - 5 } & $\begin{array}{l}\text { Survey and mapping of } \\
\text { participants initial } \\
\text { conditions }\end{array}$ & $\begin{array}{l}\text { Formulating instruments } \\
\text { to measure participants } \\
\text { abilities }\end{array}$ & $\begin{array}{l}\text { Helping to conduct } \\
\text { the survey }\end{array}$ & $\begin{array}{l}\text { Providing time and } \\
\text { place for the survey }\end{array}$ \\
\hline 2 & Modul making & Making module contents & $\begin{array}{l}\text { Assisting in module } \\
\text { layout process }\end{array}$ & Verifying the module \\
\hline 3 & Socialization & $\begin{array}{l}\text { Providing materials and } \\
\text { questions and answers }\end{array}$ & $\begin{array}{l}\text { Assisting the } \\
\text { participants }\end{array}$ & $\begin{array}{l}\text { Attending the } \\
\text { socialization }\end{array}$ \\
\hline 4 & $\begin{array}{l}\text { mentoring in a number } \\
\text { of meetings }\end{array}$ & $\begin{array}{l}\text { Providing direction and } \\
\text { helping the practice of } \\
\text { delivering aspirations } \\
\text { properly }\end{array}$ & $\begin{array}{l}\text { Assisting the } \\
\text { participants }\end{array}$ & $\begin{array}{l}\text { Attending the } \\
\text { meetings they } \\
\text { organize }\end{array}$ \\
\hline 5 & Evaluation & $\begin{array}{l}\text { Guiding the filling out of } \\
\text { evaluation sheet }\end{array}$ & $\begin{array}{l}\text { Disseminating the } \\
\text { evaluation sheet }\end{array}$ & $\begin{array}{l}\text { Filling out the } \\
\text { evaluation sheet }\end{array}$ \\
\hline
\end{tabular}

Table 2. Indicators of Activity Success

\begin{tabular}{|l|l|l|l|}
\hline No & \multicolumn{1}{|c|}{ Indicator } & \multicolumn{1}{c|}{ Pre-Activity } & \multicolumn{1}{c|}{ Post-Activity } \\
\hline 1 & Knowledge and awareness of democracy & lacking & increasing \\
\hline 2 & Ability to capture/bring up ideas & passive & creative \\
\hline 3 & Courage to deliver aspirations/ideas & passive & active \\
\hline
\end{tabular}

\section{RESULT AND DISCUSSION}

Starting this community service activity was to conduct a survey to the location to observe the initial condition of the community and conduct a mapping of the ability of community participation in their involvement in meetings both at RT, RW as well as in village level. In addition to direct observations and interviews, surveys were also conducted by distributing questionnaires to 30 villagers varied from various elements: Head of RT/RW/Village, community leaders, village officials, and ordinary people (outside of these groups).

The survey results show that community participation in meeting was low. Indifference is still inherent as a remnant of past habits (before the reform era). Some are infected with apathy as a longstanding habitual trauma in which the results of village meetings always end at the sub-district level, while the programs that are implemented are often different from the submission of the meeting results.

With such community conditions, community service activities lead to the following needs: (1) Providing knowledge and insights on democracy, especially related to the Village Law, (2) arouse public awareness of the importance of their involvement in decision making in village meetings, (3) honing skills in capturing ideas and delivering aspirations properly. 
To meet these needs, the second step is to prepare modules and other materials that are deemed necessary to carry out the activities. The selection of module materials was done by the writer and the college students assisted in the layout process.

Survey and other preparations took place since the beginning of December 2017. The peak of this community service activity was on 18 December 2017 with the presence of the Minister of Social Affairs, Khofifah Indar Parawansa who inaugurated a statue of National Hero Major General (Ret.) Prof. Dr. Moestopo. Also present at the event were the Regent of Kediri, Hj. Haryanti Sutrisno, Head and Employees of University Prof. Dr. Moestopo (Beragama), Veterans, Community Leaders, and Ngadiluwih Primary School Students.

After that, the activity continued with socialization on Village Democracy followed by mentoring the participants in a number of meetings. During the socialization, participants seemed enthusiastic in following every material presented. Participants could follow the instructions given by the speaker. Participants also did not hesitate to ask when things were difficult to understand. During socialization, the activities ran in an orderly manner. As for the mentoring stage, the community was invited to attend every meeting held. They are trained to capture ideas, be courageous to deliver aspirations and actively participate in decision making.

At the end of this activity, the community/participants have increased knowledge and democracy awareness, the ability to capture/create more creative ideas, and the courage to deliver greater aspirations/ideas.

A strategic initial step in the efforts of village democratization is focused on efforts to develop a democratic culture in the daily life of villages and village activities. This step greatly determines the process of village democratization. Developing a democratic culture means getting used to (habituation) actions to refer to democratic principles, and certainly to the noble principles known to the villagers, including local wisdom. Through the process of habituating everyday actions and in village activities, democratic principles will become alive and grow. This step can then continue by exercising control over the implementation of procedures and mechanisms of village democracy that are already in place.

\section{CONCLUSIONS}

After carrying out the socialization and mentoring on Increasing Democracy Awareness and Community Participation in the Implementation of Village Law, it can be concluded that this activity is very necessary to be held. This community service activity has a significant impact on the development of village democratic awareness especially in relation to the implementation of the Village Law. This can be seen from the conclusions extracted through the dissemination of activity evaluation sheets.

\section{REFERENCES}

Abdurokhman, D., \& Pd, M. (2014). Pengembangan Potensi Desa. Widyaiswara pada Kantor Diklat Kabupaten Banyumas.

Desa, P. M., Tertinggal, P. D., \& Nomor, D. T. R. I. (2). Tahun 2015 Tentang Pedoman Tata Tertib Dan Mekanisme Pengambilan Keputusan Musyawarah Desa. Peraturan Menteri Dalam Negeri Republik Indonesia Nomor, 114.

Naeni, A. (2015). Demokratisasi Desa. Jakarta: Kementrian Desa, Pembangunan Daerah Tertinggal, dan Transmigrasi Republik Indonesia.

Nomor, U. U. R. I. (6). tahun 2014 tentang Desa. Pemerintah Negara Republik Indonesia.(2014). Jakarta.

Rachmiatie, A. (2018). Membangun Kecerdasan Informasi dalam Peneguhan Karakter Bangsa. Jurnal Komunikasi Ikatan Sarjana Komunikasi Indonesia, 1(2), 114-121. 
Ritonga, R., Murwani, E., \& Ritonga, S. (2018). Gender Awareness of Maria Hartiningsih as Kompas Reporter. Jurnal Komunikasi Ikatan Sarjana Komunikasi Indonesia, 2(2), 82-91.

Suwignyo, A. P. D., \& Desa, S. S. P. (1986). Ghalia Indonesia.

Suyatno. (2015). Menyoal Kesiapan Pemerintahan Desa, Retrieved from http://news.metrotvnews.com/

Timur, P. P. J. (2010). Program Pemberdayaan Potensi Desa/Kelurahan. Surabaya: Bapermas Jawa Timur. 